\title{
PENGARUH BERAT KATUP PADA KERJA POMPA AIR HIDRAM
}

\author{
Zenal Abidin \\ Teknik Mesin, Universitas Galuh \\ email: Zenalabidin16@yahoo.com
}

\begin{abstract}
Atomatis haidro water pump is a water pump using a water pluid flow acceleration system in a closed thrust pipe, with mekanaika controlling the mass of the waste chamber so that it can raise water in the outlet pipe to a higher place. The mass of the valve as the waste valve as the regulator determines the performance of the pump so that it must be analyzed how much the mass of the right regulating valve for maximal tool work. The pressure of water in the pipe should be in a state of maximum pressure so that the appliance works maximally, the diameter of the output pipe adjusted to the height of water that will be streamed so that water can flow to higher levels. using a $1 \mathrm{Kg}$ valve weight and $30 \mathrm{~m}$ inlet length can produce maximum volume and pressure, compared to other tests and can generate water debit up to $6.7 \mathrm{~L}$ I min on a $173 \mathrm{~m}$ head pump. The mass weight of the valve is adjusted to the diameter and length of the pipe resulting in maximum pressure of the output tube.
\end{abstract}

Keywords ; automatic water pump control

\section{PENDAHULUAN}

Pompa air hidram digunakan sebagai solusi menaikan air ketempat yang lebih tinggi, pompa air hidram merupakan pompa air tampa bahan bakar dan listrik. Penggunaan pompa air hidaram dapat menjadi jalan keluar dalam kesulitan memasang instalasi kelistrikan dan bahan bakar untuk pompa air karena jangkauan sumber air dari pemukiman terlalu jauh. Alternatif untuk menaikan air dengan menggunakan Pompa Hidram (Hydraulic Ram Pump) berasal dari kata hidro = air (cairan), dan ram = hantaman merupakan salah satu pompa air yang hemat energi dan ramah lingkungan. Pompa hidram merupakan pompa haidro otomatis teknologi tepat guna, dalam bidang pemompaan menggunakan tenaga momentum air (water hammer) untuk menaikkan air dari suatu tempat yang lebih rendah ke tempat yang lebih tinggi. Energi potensial sumber air yang akan dialirkan dan pengaturan berat katup buang pengatur pompa hidram mengalirkan air secara kontinyu.
Pengaruh berat katup pompa air hidram sangant menentukan debit air pada pipa pengantar sehingga dapat dianalisis lebih lanjut, perbandingan berat katup buang yang tepat dengan diameter dan panjang pipa pendorong dapat menentukan kerja pompa air hidram bekerja maksimal.

\section{KAJIAN PUSTAKA}

Berat pada katup pompa hidram yang terjadi pada benda dapat menyebabkan perpindahan pada arah gravitasi, pada saat kehilangan tekanan pada pipa pendororng katup dapat membuka saluiran pembuangan.

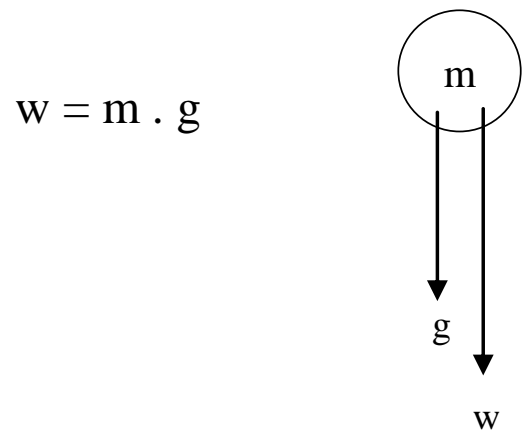

Computer Science | Industrial Engineering | Mechanic Engineering | Civil Engineering 
Gambar 1. Diagram kebebasan benda

Pada gambar 1.1 menunjukan Sesuai dengan persamaan di atas berat katup benda ditulis dengan: $\quad \mathrm{W}=\mathrm{m} . \mathrm{g}$

Dimana :

$\mathrm{m}=$ massa katup $(\mathrm{kg})$

$\mathrm{w}=$ berat katup (newton)

$\mathrm{g}=$ percepatan gravitasi $\left(\mathrm{m} / \mathrm{s}^{2}\right)$

Penelitian Budi Hartono (2016) dengan judul pengaruh variasi tabung udara terhadap debit pemompaan pompa hidram, berdasarkan penelitiannya menujukkan bahwa penggunaan tabung udara dapat memperbesar head output pompa hidram. Melihat dari kajian yang sudah ada, banyak faktor yang mempengaruhi efisiensi pompa hidram akibat adanya proses water hammer yang terjadi dalam tabung udara. Tabung udara juga berfungsi meningkatkan tekanan untuk mendorong air keluar melewati lubang pipa tekan, namun dalam pengoperasian dilapangan dapat dijumpai air tidak sampai pada tempat tujuan dan jumlah air pun sedikit akibat ukuran tabung udara yang tidak sesuai sehingga pompa bekerja lebih keras lagi. Karena itu, diperlukan juga penelitian tentang pengaruh penggunaan diameter tabung udara yang secara teoritis dimaksudkan untuk mendapatkan aliran yang kontinyu dan untuk mengurangi konsumsi daya. Rumusan masalah dari penelitian ini adalah sejauh mana volume tabung udara yang optimal digunakan untuk mengalirkan air. Penelitian ini bertujuan untuk mengetahui pengaruh variasi volume tabung udara terhadap efisiensi pompa hidram.

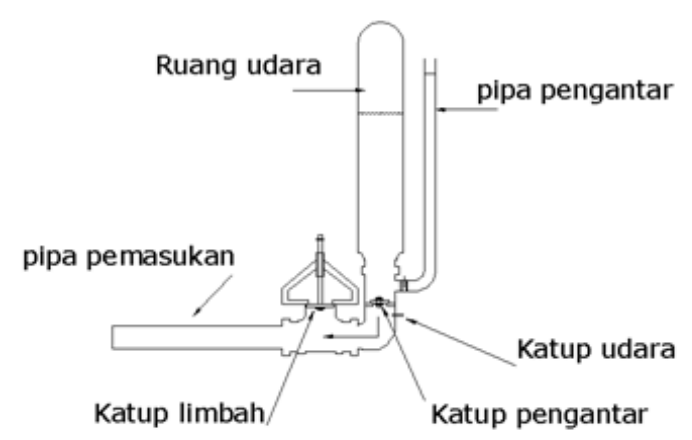

Gambar 2. Skema katup limbah pada Pompa Hidram

Gambar 2. menyatakan pompa hidram merupakan pompa yang memanfaatkan water hammer (palu air) sebagai tenaga utama untuk menaikkan air dari sumber air yang tidak terlalu tinggi menuju ke tempat yang lebih tinggi dari sumber air tersebut. Pompa hidram belakangan ini sudah banyak dipakai dan dilakukan penelitian khususnya pada daerah perbukitan dan daerah yang memiliki aliran air yang jauh dari pemukiman serta lahan pertanian. Tujuan penelitian ini untuk mengetahui variasi tabung udara terhadap output dan efisiensi pompa hidram dengan menggunakan metode eksperimen penelitian dan pengambilan data.

Penelitian yang dilakukan oleh Dinar M. F. Dkk (2013) dalam penelitiannya yang berjudul uji efisiensi pompa hidram degan variasi volume tabung udara, dapat diambil kesimpulan bahwa variasi volume tabung udara tidak memberikan pengaruh yang signifikan terhadap efisiensi pompa hidram. Rancang bangun pompa hidram yang menghasilkan efisiensi terbaik adalah pompa hidram dengan volume tabung udara $1500 \mathrm{ml}$ dengan efisiensi sebesar 17,21\%.

Sedangkan pada penelitian Andrea Sebastian Ginting dan M. Syahril Gultom (2014) dalam penelitiannya yang berjudul 
analisa pengaruh variasi volume tabung udara dan variasi beban katup limbah terhadap performa pompa hidram, diperoleh hasil bahwa faktor volume tabung udara, beban katup limbah dan head supply berpengaruh pada efisiensi pompa hidram.

Dari beberapa reperenci penelitian di atas tabung merupakan alat untuk menyimpan tekanan semantara pada pipa keluaran,paktanya tekanan maksimal diatur oleh pencepatan maksimal dipipa pendorong pada saat di tutup dengan massa yang tepat pada katup limbah.

\section{METODE PENELITIAN}

Metode penelitian dilakukan untuk mengetahui parameter dalam berat katup buang pompa air hidram berapakah perbandingan berat katup buang yang tepat dengan diameter dan panjang pipa pendorong sehingga mencapai debit air maksimal.

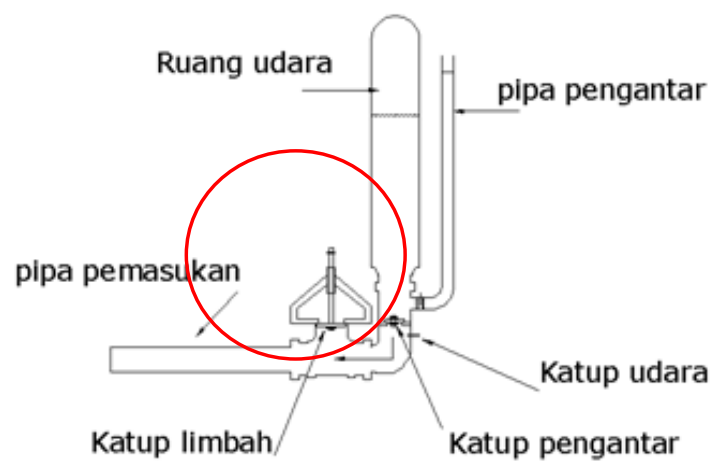

Gambar 3. Massa katup sebagai katup buang

Pada gambar 3.1 massa katup sebagai katup buang menentukan berat katup dapat menyebabkan perpindahan pada arah gravitasi.

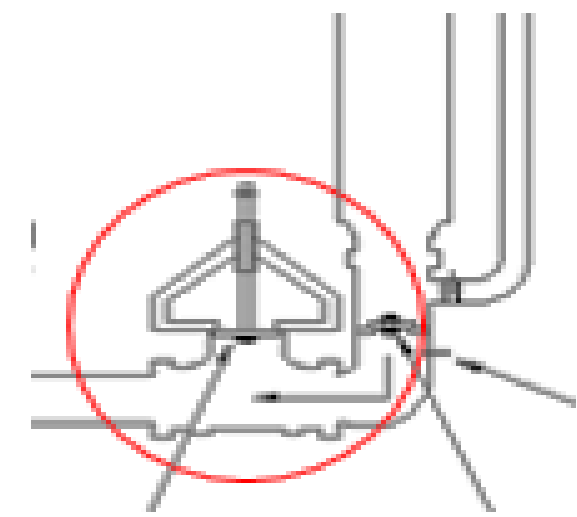

Gambar 4. Berat katup buang

Gambar 4.1 berat katup buang ditambah untuk mencari berapa berat maksimal sehingga keluaran debit air yang keluar mencapai maksimal, pengujian dilakukan dengan berat katup tiga tingkat, pipa masuk tiga tingkat dan pipa penghantar (head pam) tiga tinggkat.

\section{HASIL PEMBAHASAN}

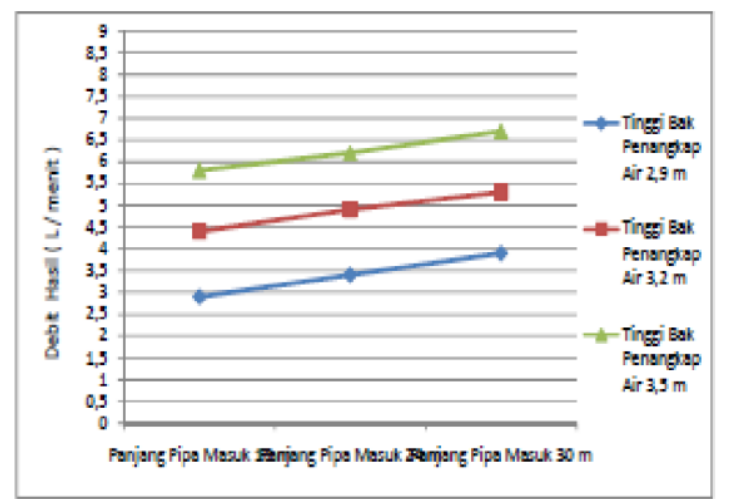

Gambar 1. Grapik kenaikan tekanan air berdasarkan berat massa katup

Gambar grafik 1.1 menyatakan hubungan antara pipa pendorong dengan variasi berat katup terhadap debit yang dihasilkan 


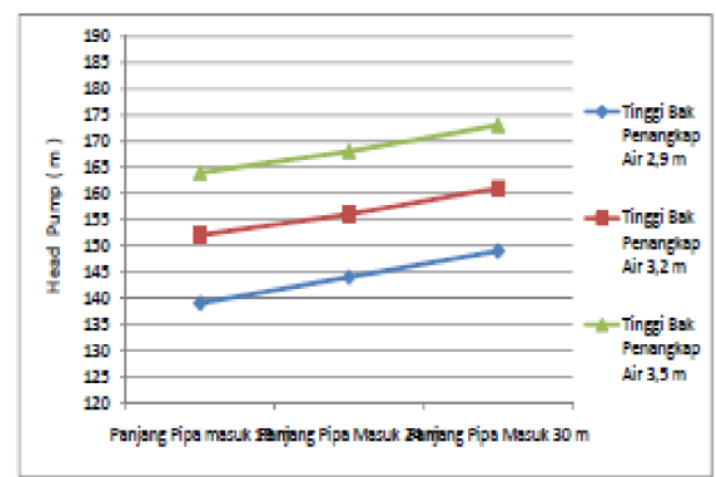

Gambar 2. Grapik kenaikan tekanan air berdasarkan berat katup

Gambar grafik 1.1 grapik kenaikan tekanan air berdasarkan berat katup menyatakan hubungan antara pipa pendorong dengan berat katup. Berdasarkan grafik dilihat bahwa setiap panjang pipa masuk dilakukan 3x percobaan, dengan tujuan mendapatkan hasil yang lebih valid, pada pengujian tersebut menunjukan analisa debit air yang diambil dari ketinggian (h) $173 \mathrm{~m}$ pada kondisi vertikal dan panjang pipa keluar $200 \mathrm{~m}$ pada sudut kemiringan $60^{\circ}$.

Tabel 1. Debit pemompaan

\begin{tabular}{cccc}
$\begin{array}{c}\text { Berat } \\
\text { katup } \\
(\mathrm{kg})\end{array}$ & $\begin{array}{c}\text { Panjang } \\
\text { pipa } \\
\text { masuk } \\
\text { (meter) }\end{array}$ & $\begin{array}{c}\text { Head } \\
\text { pam } \\
\text { (meter) }\end{array}$ & $\begin{array}{c}\text { Debit air } \\
\text { (liter/menit) }\end{array}$ \\
\hline 0,500 & 18 & 139 & 2,9 \\
& 24 & 144 & 3,4 \\
& 30 & 149 & 3,9 \\
0,750 & 18 & 152 & 4,4 \\
& 24 & 156 & 4,9 \\
& 30 & 161 & 5,3 \\
1 & 18 & 164 & 5,8 \\
& 24 & 168 & 6,2 \\
& 30 & 173 & 6,7 \\
\hline
\end{tabular}

Tabel 1. debit pemompaan menyatakan berdasarkan dari hasil data tabel dan grafik diatas menggunakan berat katup $1 \mathrm{Kg}$ dan panjang pipa masuk $30 \mathrm{~m}$ dapat menghasilkan volume dan tekanan yang lebih maksimal, dibandingkan dengan pengujian yang lainnya dan dapat menghasilkan debit air hingga mencapai 6,7 L/menit pada head pump $173 \mathrm{~m}$ dengan kondisi vertikal.

\section{KESIMPULAN}

Berat katup ditambahkan semaksimal mungkin dan disesuaikan dengan diameter dan panjang pipa sehingga menghasilkan debit air keluar maksimal.

\section{REPARENSI}

Widarto, L. \& FX. Sudarto C. Ph. (2000). "Teknologi Tepat Guna: Membuat Pompa Hidram”. Kanisius. Yogyakarta.

Wahyudi, S. I. dan Fachrudin, F. (2008). "Korelasi Tekanan dan Debit Air Pompa Hidram Seba gai Teknologi Pompa Tanpa Bahan Bakar Minyak”. Jurnal Ilmiah Teknik Sipil ,Universitas Sultan Agung, Semarang.

Hartono, B. (2016). "Pengaruh Variasi Tabung Udara terhadap Debit Pemompaan Pompa Hidram". Banten: Jurnal SINTEK. Vol. 8.NO.1:25-xviii.

Andrea Sebastian Ginting dan M. Syahril Gultom. (2014). “Analisa Pengaruh Variasi Volume Tabung Udara dan Variasi Beban Katup Limbah terhadap Performa Pompa Hidram". Sumatera Utara: Jurnal e-Dinamis. Vol.9 No.1:47-56

Arianta, Ahmad Nur. 2010. Pengaruh Variasi Ukuran Tabung Udara Terhadap 
Unjuk Kerja Sebuah Pompa Hidram.

Diambil dari:

https://www.slideshare.net/mobile/rand u29/61607365-pompahidram. Diakses pada 17 Februari 2017.

Gatut Prijo Utomo, et al. 2015. Analisa Pengaruh Tinggi Jatuhan Air Terhadap Head Pompa Hidram". Surabaya: Jurnal Pengabdian LPPM Untag. Vol. 01,No. 02:211-224.

Suarda, M., Wirawan, IKG.,2008, Kajian Eksperimental Pengaruh Tabung Udara pada Head Tekanan Pompa Hidram, Jurnal Ilmiah Teknik Mesin CAKRAM, Vol. 2, No.1:10-14

Daryanto. 2003. Fisika Teknik. Jakarta: PT.BINA ADIAKSARA dan PT.RINEKA CIPTA.

Streeter, Victor L. dan Wylie, E. Benjamin. 1985. Mekanika Fluida. Jakarta: Erlanga. 
Jurnal J-Ensitec: Vol 04|No. 02, Mei 2018

Computer Science | Industrial Engineering |Mechanic Engineering | Civil Engineering 